\section{Reinforcing National Security and Regional Stability The Implications of Nuclear Weapons and Strategies}

MUTHIAH ALAGAPPA

Another major conclusion of this study is that although nuclear weapons could have destabilizing consequences in certain situations, on net they have reinforced national security and regional stability in Asia. It is possible to argue that fledgling and small nuclear arsenals would be more vulnerable to preventive attacks; that the related strategic compulsion for early use may lead to early launch postures and crisis situations; that limited war under nuclear conditions to alter or restore the political status quo can intensify tensions and carry the risk of escalation to major war; that inadequate command, control, and safety measures could result in accidents; and that nuclear facilities and material may be vulnerable to terrorist attacks. These are legitimate concerns, but thus far nuclear weapons have not undermined national security and regional stability in Asia. Instead, they have ameliorated national security concerns, strengthened the status quo, increased deterrence dominance, prevented the outbreak of major wars, and reinforced the regional trend to reduce the salience of force in international politics. Nor have nuclear weapons had the predicted domino effect. These consequences have strengthened regional security and stability that rest on multiple pillars.

The grim scenarios associated with nuclear weapons in Asia frequently rely on worst-case political and military situations; often they are seen in isolation from the national priorities of regional states that emphasize economic development and modernization through participation in regional and global economies and the high priority accorded to stability in domestic and international affairs. The primary goal of regional states is not aggrandizement through military aggression but preservation of national integrity, state or regime survival, economic growth and prosperity, increase in national power and international influence, preservation or incremental change in the status quo, and the construction of regional and global orders in which they are subjects rather than objects. Seen in this broader perspective, nuclear weapons and more generally military force are of greater relevance in the defense, deterrence, and assurance roles than offensive ones. This does not imply that offensive use of force or military clashes will not occur; only that force is not the first option, that military clashes will be infrequent, and that when they do occur they will be limited in scope and intensity. Security interaction in Asia increasingly approximates behavior associated with defensive realism.

The study advances four other propositions on the implications of nuclear weapons and strategies for security and stability in the Asian security. region and for the global nuclear order. First, it argues that nuclear weapons have a modifying effect, but they do not fundamentally alter system structure (distribution of power) or the patterns of amity and enmity. By strengthening weaker powers, nuclear weapons have helped offset imbalances in conventional and nuclear capabilities and mitigated the negative consequences of those imbalances. This has affected the distribution and effects of military power in certain bilateral relationships. However, nuclear weapons in and of themselves have not substantially altered the overall regional distribution of power. Likewise, nuclear weapons have not fundamentally altered patterns of amity and enmity in the Asian security region. The one exception may be in the Middle East where a nuclear Iran could bring into sharper relief the Israel-Iran line of enmity and temper that between Israel and certain Arab states (though not the Palestinians). This is still a hypothetical situation, and Israel-Iran enmity is not only a function of nuclear weapons. A nuclear Iran could substantially alter the Middle East security dynamics, broaden and increase the connection of that region to South Asia, and increase the subregion's relevance for regional and global security. In all other Asian subregions, nuclear weapons have not altered security patterns but have affected the intensity of existing security dilemmas. Offensive strategies including first use have intensified certain security dilemmas; deterrence strategies by and large have had ameliorating effects.

Second, the impact of nuclear weapons on alliance formation and sustenance is mixed. In the abstract, nuclear weapons should enhance internal balancing and reduce the need for external balancing; this should reduce the significance of alliances. In certain ways this has been the case with Pakistan, Israel, and North Korea. All these countries see nuclear weapons as enhancing their self-reliant deterrence capability and as their ultimate security guarantee. However, nuclear weapons have not reduced the salience of alliance and alignment relationships for these countries. Nuclear weapon states may still choose to ally or align with each other for different benefits. For nonnuclear weapon states that perceive nuclear or large-scale conventional threats, alliance with a state that can effectively extend the deterrence function of its nuclear arsenal remains attractive. Concern with 
nuclear threats, along with other considerations, has strengthened the U.S. alliance relationships with Japan, South Korea, and Australia. In certain situations, concern with nuclear threat could also challenge and weaken these alliances.

Third, on conflict resolution, the study posits that the enormous destructive power of nuclear weapons argues against dispute resolution through the physical use of violence. At the same time, nuclear weapons are not a barrier to peaceful conflict resolution. In fact, the grave risks associated with escalation to nuclear war have occasionally induced parties to explore a diplomatic settlement. The settlement of disputes, however, requires conflicting parties to negotiate compromises on political differences. In the absence of such compromise, nuclear weapons can freeze and intensify conflicts.

Finally, the study posits that if it is to continue to be relevant, the nuclear order that emerged during the Cold War must substantially alter to accommodate contemporary strategic realities, including a focus on Asia, which has becomea core world region and in which strategic competition is likely to intensify. A "new" nuclear order that is likely to emerge gradually would have to address at least four challenges: (I) sustaining deterrence in a condition of asymmetry and small nuclear forces, (2) accommodating "new" nuclear weapon states, (3) preventing the spread of nuclear weapons to additional states and to nonstate actors, and (4) facilitating the safe and secure development of nuclear energy to meet the growing demand for this clean fuel. Freezing the twentieth-century order would be counterproductive. The gap between the formal order and reality would widen and undermine its viability and effectiveness.

The findings on the roles and implications of nuclear weapons in this study may appear too "benign" and unacceptable to those who view nuclear weapons as the primary drivers of insecurity and arms control, especially nonproliferation scholars and advocates who see preventing the spread of nuclear weapons and their eventual elimination as urgent ends in themselves. Regardless of intellectual and moral persuasions, nuclear weapons will be a feature of the Asian security landscape in the foreseeable future. The ethics of responsibility requires us to investigate and address all their security implications, not just the negative consequences of proliferation. In this connection, security studies and arms control scholarship in the twenty-first century should illuminate, develop, and subject the "new" roles and strategies for the employment of nuclear weapons to more rigorous analysis and contribute to deterrence stability in a condition of asymmetric power relationships. Strategic dialogue among nuclear weapon states that fosters common understandings can also contribute to stability.

\section{Nuclear Weapons Reinforce Security and Stability}

Three contending views have been advanced on the consequence of nuclear weapons for peace and security in Europe during the Cold War. One view is that nuclear weapons contributed to the long peace and stability in Europe (Gaddis 1992; Jervis 1988; Waltz 2004). ${ }^{1}$ The second view does not contest the idea of a long peace but disputes that nuclear weapons contributed to it (Mueller 1988, 1998). The third view contests the claim that the Cold War was a period of stable peace. In this view, the nuclear standoff during the Cold War was highly dangerous and should be avoided. In terms of relevance for the contemporary era, some Western analysts (mostly nonproliferation scholars and advocates) argue that the contribution of nuclear weapons to the long peace in Europe would not apply to Asia. Asian countries are culturally different; their militaries view preventive war in a favorable light and are not interested in developing invulnerable strategic forces; and insecure command and control arrangements make them more prone to accidents and unauthorized use (Feaver 1992-93, I993; Sagan 1994, 1995). Adherents of this perspective argue that the Indian, Pakistani, and most recently North Korean nuclear tests would set off a domino effect, with negative consequences for security and stability in Asia and the world. Their arguments connect with the third perspective, which argues that the Cold War nuclear confrontation was highly dangerous, the peace that existed was highly tenuous, Europe was lucky to escape the nightmare scenario, and Asia should at all cost avoid repeating that scenario. ${ }^{2}$ The view that nuclear weapons would contribute to insecurity and instability in Asia seems to have become dominant in the West, especially in the wake of the 1999 and 2002 crisis situations between India and Pakistan and the 2006 North Korean nuclear test. It resonates with and reinforces earlier views in Europe and the United States that Asia was ripe for rivalry and that its future would resemble the war-torn Europe of the nineteenth century (Buzan and Segal 1994; Friedberg 1993-94).

In 2003 I argued against the "ripe for rivalry" line of thought, pointing out that Asia had enjoyed relative peace and security for over two decades (now three decades) and that a relatively stable security order based on several pillars had developed in the region (Alagappa 2003a, 2003b). There has not been a major war since the Vietnamese invasion of Cambodia in 1978 and the Chinese punitive attack on Vietnam in 1979. Despite periodic tensions, war has not broken out across the Taiwan Strait or on the Korean peninsula. There has been more military conflict between India and Pakistan, and the probability of an overt military clash between those two countries is higher than in the other two conflicts. Even there, though, and in some ways because of the acquisition of nuclear weapon capabilities, the use of force has been limited and largely confined to the areas adjacent to the line of control (LoC) in Kashmir. The 1999 Kargil conflict did not escalate to a full-scale war. The many territorial disputes in Asia have resulted in only occasional and limited military clashes. Historical memories and contemporary concerns linked to a dominant United States and a rapidly rising China have created mistrust, apprehensions, and long-range threat perceptions among major powers. 
Such apprehensions and threat perceptions may intensify competition for power and influence, but they have not resulted in vigorous strategic rivalry and arms competition. Nor has Asia become a hotbed of wars where the survival of states is at issue and countries are constantly jockeying for power.

International political interaction among Asian states is for the most part rule governed, predictable, and stable. The security order that has developed in Asia is largely of the instrumental type, with certain normative contractual features (Alagappa $2003 \mathrm{~b}$ ). It rests on several pillars. These include the consolidation of Asian countries as modern nation-states with rule-governed interactions, widespread acceptance of the territorial and political status quo (with the exception of certain boundary disputes and a few survival concerns that still linger), a regional normative structure that ensures survival of even weak states and supports international coordination and cooperation, the high priority in Asian countries given to economic growth and development, the pursuit of that goal through participation in regional and global capitalist economies, the declining salience of force in Asian international politics, the largely status quo orientation of Asia's major powers, and the key role of the United States and of regional institutions in preserving and enhancing security and stability in Asia.

I extend that argument in this study to include the effects of nuclear weapons and the strategies for their employment. I argue that although there could be destabilizing consequences, on net, nuclear weapons reinforce deterrence dominance and enhance national security and regional stability in the Asian security region. My claim is supported on the following grounds. First, nuclear weapons assuage the security concerns of vulnerable states. Second, nuclear weapons prevent the escalation of regional conflicts to full-scale war. Third, general deterrence postures assure major powers and help stabilize relations among them. Fourth, nuclear weapons strengthen the political and military status quo by making violent change highly dangerous and unlikely. Finally, nuclear weapons further circumscribe and transform the role of force in Asian international politics. Taken together, these political and military effects of nuclear weapons, along with the absence of intense strategic rivalry and competition among the major pow ers, reinforce the security and stability that have come to characterize the Asian security region over the last three decades. My argument shares certain features of those advanced by Waltz (1995), Hagerty (1998), and Goldstein (2000), but it is also distinct and grounded in two decades of post-Cold War regionwide experience and linked to other political, strategic, and economic factors that also underpin security and stability in the region. It is important to view the roles and effects of nuclear weapons in this larger context.

Critics would contest my claim by pointing to the crisis situations in IndiaPakistan relations during the 1999-2002 period, the abstract shortcomings of general deterrence, and the potential domino effect of the Indian, Pakistani, and
North Korean nuclear test. They would also draw attention to two other sets of issues. One set relates to strategic considerations, including the danger of preemptive and preventive action, and the strategic incentive to use a small nuclear arsenal early for fear of losing it in a preemptive strike. The second set relates to dangers that are deemed peculiar to new nuclear weapon states: command-andcontrol problems, safety issues, the risk of nuclear weapons falling into the wrong hands (extremist groups and rogue regimes, which cannot be deterred because of their irrational behavior), and the dangers associated with nuclear weapons in a failed or failing state. I discuss the strategic arguments in the context of developing and supporting my argument. Here I briefly address the second set of issues.

The risks associated with new nuclear weapon states are indeed plausible and should be of concern. It would take me too far afield to contest the biased assumptions that inform some of these claims in relation to non-Western nuclear weapon states. I would like to make three general points. First, the logic of risk and that of strategic need are different and should be addressed separately. Conflating them makes for a crosspurpose debate that is unproductive. The risk argument is advanced by those who oppose the acquisition and development of nuclear weapon capability by developing countries. Intellectual (and possibly racial) biases and national strategic interests are often cloaked in this argument, which is usually advanced on behalf of the international community. Proponents of this persuasion deny the security need or the relevance of nuclear weapons for that need, and they advance political, status, and bureaucratic arguments as the "real" reasons underlying the quest for a nuclear weapon capability. The country that is seeking the capability advances the strategic logic. That country's political leadership believes that the acquisition of nuclear weapon capability is vital to secure its national interest even if it entails high cost. It is not unaware of the risks, but these are trumped by the security imperative. The logic of risk cannot be the basis for self-denial of a capability deemed vital in a self-help world. An enterprise cannot be forbidden, especially on discriminatory grounds, simply because it entails risks for the so-called international community.

The new nuclear weapon states recognize the command, control, and safety problems and have taken measures to prevent accidents and theft. Outsiders should consider assisting those states by providing suitable technologies and best practices instead of simply isolating and castigating them. Safety of the nuclear arsenal in an unstable state, such as Pakistan, is indeed a serious concern. That concern must be addressed on a case-by-case basis with specific policies but not by a blanket policy that applies to all developing countries. Pakistan has instituted certain measures to safeguard its arsenal and prevent unauthorized use (see Khan and Lavoy, Chapter 7 of this volume). Out of fear that these weapons may fall into the hands of Islamic extremist groups, the United States has assisted in these efforts as well (Sanger and Broad 2007). The strategic logic has to be addressed on its own terms by those 
acting on behalf of the international community. The United States, for example, is now willing to provide security assurances to the Kim Jong II regime in the context of the Six-Party Talks to negotiate a settlement of the North Korean nuclear problem. In certain cases, the security need cannot be addressed satisfactorily. And those acting on behalf of the international community (authorized and unauthorized) may have to forcibly eliminate the target state's nuclear capability or will have to live with a new nuclear weapon state. It has been done before.

Second, the new states recognize the revolutionary nature of nuclear weapons; they are not immune to the strategic logic of these weapons. They have not behaved differently from the "rational" Western states. Just like the United States, Russia, Britain, and France, "new" countries see nuclear weapons as being useful in a deterrence role. They are in the process of developing more survivable forces but doing it responsibly in the context of other national priorities, avoiding intense arms competition that characterized the interaction of the advanced countries during the Cold War. Some new nuclear weapon states have attempted offensive strategies in the employment of nuclear weapons, but this attempt is not peculiar to them. The United States is in the forefront in developing offensive and strategic defense capabilities that some Asian states consider destabilizing.

Third, the claim that so-called rogue states cannot be deterred does not withstand scrutiny. The Soviet Union was a revolutionary state seeking to fundamentally transform the international order. Yet deterrence was the primary nuclear strategy in dealing with that country. Deterrence was also the strategy against a China that under Mao was deemed a rogue and irrational state, especially during the Cultural Revolution. Characterization of China as a revolutionary state also did not stop the United States from negotiating with Mao and forming a strategic alignment with that country against the Soviet Union. Despite the claim that rogue states cannot be deterred, deterrence (conventional and nuclear) has been and continues to be the primary U.S. strategy against North Korea. The United States is now negotiating with a regime that it labels as irrational and tyrannical in an effort to freeze and eliminate North Korea's nuclear weapon capability. Certain frustrated arms controllers in the United States now attempt to depict India, the world's largest democracy and the fourth or fifth largest economy in terms of purchasing power parity, as a rogue state, although the Bush administration through its bilateral deal with India is seeking to bring that country into the formal nuclear order. The ongoing debate in Asia over the pros and cons of a first-use policy is not much different from that in the Atlantic alliance during the Cold War or that in post-Cold War Russia. The point here is that the nuclear behavior of non-Western states is not substantively different from that of Western ones. Further, a country like the United States, which has a formidable nuclear arsenal, can deter them. I now turn to supporting my claim that nuclear weapons have contributed to security and stability in Asia.

\section{Assuage Security Concerns}

Nuclear weapons contribute to stability by assuaging the security concerns of vulnerable states. This is most evident in the case of Pakistan. Islamabad sees nuclear weapons as having enhanced its security in relation to the existential threat it perceives from India (see Khan and Lavoy, Chapter 7 of this volume). Nuclear weapons neutralize the effects of the large imbalance in conventional military capability, constrain India's military options, and increase Pakistan's deterrence selfreliance. The security effect of an opaque nuclear force like that of Israel is more difficult to demonstrate, especially as that country also has superior conventional military capability. Avner Cohen suggests that Israel has been able to "extract the benefits of an existential nuclear deterrence posture" (see Cohen, Chapter 8 of this volume). Arab countries' tacit acceptance of Israel's nuclear deterrence posture, he argues, has contributed to Israel's security and to regional stability by lowering the intensity of the Arab-Israeli conflict, and in some instances even contributed to peace settlements, like that between Israel and Egypt. Cohen posits that Israel's nuclear capability possibly compelled Saddam Hussein to limit his missile attacks on Israel during the First Gulf War to conventional weapons. Although Israel has superior conventional military capability, nuclear weapons enhance Israel's selfconfidence and demonstrate its resolve to survive.

For North Korea, nuclear weapons serve a more immediate deterrence function against the United States. Though still numerically large, North Korea's conventional military capability has steadily eroded and is losing the balance-ofpower advantage it had enjoyed for decades. North Korea has also lost the military support of Russia and China. In this context, North Korea's nuclear weapon capability assumes greater importance. Pyongyang believes that nuclear weapons enhance its security and provide it with diplomatic leverage in the Six-Party Talks for securing tangible security, diplomatic, and economic benefits (see Park and Lee, Chapter 9 of this volume). It is a fact that U.S. policy has shifted from a rigid stance that stressed the preventive force option and demanded complete and verifiable disarmament of the North Korean nuclear weapon program to serious engagement in multilateral discussions to arrive at a diplomatic settlement with due regard to Pyongyang's concerns. Several considerations underlie the shift in U.S. policy. North Korea's determination to stay the course, culminating in the 2006 nuclear test, appears to be one of them. Of particular relevance is the impact of Pyongyang's missile and nuclear tests on America's East Asian allies and the ensuing imperative to limit the fallout from those tests.

The U.S. extended deterrence commitments have been a significant factor in assuaging the security vulnerabilities and concerns of Japan and South Korea in the wake of the North Korean nuclear test. As discussed in Chapter 17, both countries insisted on reaffirmation of the U.S. commitment, and Japan is exploring 
measures to increase the credibility of that commitment. In reassuring Japan, the U.S. commitment is a significant factor along with others in forestalling exploration of an independent nuclear option by that country. For South Korea, the U.S. commitment enables it to maintain a nonnuclear posture, provides time to build a self-reliant defense capability, and is a fallback in dealing with a nuclear-armed North Korea.

\section{Help Stabilize Regional Conflicts}

Nuclear weapons contribute to regional stability by preventing the outbreak of major hostilities and their escalation to full-scale war in key regional conflicts across the Taiwan Strait, on the Korean peninsula, and over Kashmir. The restraining effect of nuclear weapons in the Taiwan and Korean conflicts has been discussed in Chapter 17. The fear of escalation to the nuclear level limits China's force options and implicitly deters a major Chinese attack on Taiwan. The United States' response to Chinese threats and intimidations has been calibrated to show firmness and caution. Washington has also reined in provocative behavior by independence-oriented Taiwanese leaders. Similarly nuclear weapons help stabilize the conflict on the Korean peninsula. North Korea feels more assured of its deterrence capability while South Korea is assured by the U.S. extended deterrence commitment. It is possible to argue that there has not been a deep crisis in the conflict across the Taiwan Strait to demonstrate the restraining and stabilizing effect of nuclear weapons and, further, that stability in the Taiwan and North Korea conflicts is due to a number of factors including conventional deterrence. It is difficult to refute these claims, as the deterrence effect of nuclear weapons cannot be isolated and quantified in the absence of severe crisis when the role and effect of such weapons come into sharper relief. However, this does not imply irrelevance or that nuclear weapons do not contribute to stability.

The stabilizing effect of nuclear weapons may be better illustrated in IndiaPakistan relations, as the crises between these two countries during the r9992002 period are often cited as demonstrating nuclear weapon-induced instability. Rather than simply attribute these crises to the possession of nuclear weapons, a more accurate and useful reading would ground them in Pakistan's deliberate policy to alter the status quo through military means on the premise that the risk of escalation to nuclear war would deter India from responding with full-scale conventional retaliation; and in India's response, employing compellence and coercive diplomacy strategies. In other words, particular goals and strategies rather than nuclear weapons per se precipitated the crises. Further, the outcomes of these two crises revealed the limited utility of nuclear weapons in bringing about even a minor change in the territorial status quo and highlighted the grave risks associated with offensive strategies. Recognition of these limits and the grave consequences in part contributed to the two countries' subsequent efforts to engage in a comprehensive dialogue to settle the many disputes between them. The crises also led to bilateral understandings and measures to avoid unintended hostilities.

Though it is too soon to take a long view, it is possible to argue thąt, like the Cuban missile crisis in 1962 , the 1999 and $200 \mathrm{r}-02$ crises between India and Pakistan mark a watershed in their strategic relations: the danger of nuclear war shifted their focus to avoiding a major war and to finding a negotiated settlement to bilateral problems. Large military deployments along the common border and Pakistan-supported insurgent activities in India continue; and the two countries regularly conduct large-scale military exercises and test nuclear-capable missiles that have each other's entire territory within range. Despite these activities, the situation has become less tense; stability with the ability to absorb shocks has begun to characterize the bilateral relationship over the past five years. Some have termed this "ugly stability" (Tellis 1997: 5 ), but it is stability nevertheless.

\section{Assurance and Stability in Major Power Relations}

The caution induced by nuclear weapons, their leveling effect, the strategic insurance they provide to cope with unanticipated contingencies, and general deterrence postures inform and circumscribe interaction among the major powers, reduce their anxieties, and constrain the role of force in their interaction. This enables major powers to take a long view and focus on other national priorities. Nuclear weapons feature primarily in deterrence and insurance roles. These roles are not necessarily threatening to other parties. Modernization of nuclear arsenals and the development of additional capabilities have proceeded at a moderate pace; they have produced responses but not intense strategic competition. The net effect has been stabilizing.

The stabilizing effect of nuclear weapons in the Sino-American, RussoAmerican, and Sino-Indian dyads were discussed in Chapter 17 . Here I will limit myself to making some additional points. Continuing deterrence dominance underlies China's measured response to the U.S. emphasis on offensive strategies and its development of strategic missile defense. Perceiving these as undermining the robustness of its strategic deterrent force, China seeks to strengthen the survivability of its retaliatory force and is attempting to develop capabilities that would threaten American space-based surveillance and communications facilities in the event of hostilities. However, these efforts are not presented as a direct challenge to or competition with the United States. Beijing has deliberately sought to downplay the modernization of its nuclear force. This is not simply deception, but a serious effort to develop a strong deterrent force without entering into a strategic competition with the United States, which it cannot win due to the huge imbalance in military capabilities and technological limitations. Strategic competition will also divert attention and resources away from the more urgent modernization goals. A strong Chinese strategic deterrent force blunts the military 
advantage of the United States, induces caution in that country, and constrains its military option in the event of hostilities. Although Russia's response to the U.S. development of offensive and strategic defense capabilities has been more vocal, it lacks specifics. Moscow also does not appear to have allocated significantly more resources to its nuclear force.

India's strategic deterrence force does not compare with China's, but its nuclear, missile, and conventional military capability give New Delhi a relatively high degree of self-confidence in managing relations with Beijing. The insurance provided by its small nuclear force and strong conventional capability, combined with technological and resource limitations, and improving bilateral relations, explain India's gradual development of a nuclear deterrent capability against China. India's minimum deterrence nuclear posture and its gradual nuclear buildup also reassure China, which sees the United States as its principal security concern. In recent times, Japan has been more sensitive than India to China's nuclear force modernization and the development of North Korea's missile and nuclear capabilities. In part, this is due to the lack of its own nuclear weapon capability. However, Japan has not sought its own nuclear weapon capability to compete with China or North Korea, a move that could be destabilizing. Instead it has sought reaffirmation of the U.S. extended deterrence commitment, denuclearization of the Korean peninsula, increase in its own conventional military capability, and development of strategic defense, all of which can be stabilizing.

Because they are not immediately threatening, the general deterrence postures adopted by all the major powers have contributed to regional stability as well. Patrick Morgan (2003: 80-II5) has written that government leaders are "often barely moved by general deterrence threats that they ought to take into account." Because the response to it is uncertain, he argues that general deterrence suffers an inherent credibility problem and is vulnerable to military probes that could lead to deterrence failure. It is possible to depict the Chinese missile firings in $1995^{-96}$ and the I999 Pakistani military infiltration into Kargil as probing the general deterrence postures of the United States and India, respectively. The firm and quick response in both cases established the credibility of American commitment to the status quo across the Taiwan Strait and the Indian determination to preserve the status quo in Kashmir. When established, immediate deterrence (as opposed to general deterrence, although the difference between the two is not clear-cut) may be more credible, but this is not certain. But immediate deterrence may not be relevant or practical in all situations. In the absence of intense hostilities or a lack of capabilities, a nuclear weapon state is more likely to adopt a policy of general deterrence. The risk of escalation to nuclear war and the devastation that can be inflicted by nuclear weapons make general deterrence more effective than conventional deterrence. Periodic demonstration of resolve may be necessary to shore up the credibility of general deterrence. From the perspective of stability, which is the primary issue addressed here, general deterrence is less directly threatening than immediate deterrence and more effective than conventional deterrence. It does not aggravate security relations or feed competitive strategic armament; and it is more defensive in character than immediate deterrence, which can have a strong aggressive component. All these features of general deterrence contribute to stability.

\section{Reinforce the Political and Military Status Quo}

Reviewing the Cold War experience, Robert Jervis has argued that nuclear weapons strengthen the status quo. However, he qualified that assertion by excluding situations where the status quo is ambiguous or when a revisionist power has the power to implement threats, has high resolve, and sees the domestic and international situations as precarious enough to merit great risk and cost (Jervis I989: 32-34). Along these lines but in a more detailed fashion, Paul Kapur (2006) argues that nuclear weapons may provide incentives for a weaker, revisionist state to engage in limited conventional military action to alter the status quo. Such a state would not engage in aggressive behavior in a conventional world because it would most likely result in failure. In a nuclear world, the stronger state is inhibited from employing its full military might for fear that hostilities would escalate to nuclear war. This risk of escalation emboldens a highly motivated state to behave aggressively.

In this study, I argue that the risk of escalation cuts both ways and that the net effect of nuclear weapons has been to reinforce the status quo and enhance stability in the Asian security region in two ways: they make change through violence more difficult and highly costly; and they dramatically increase the political cost of "adventurist" behavior by nuclear weapon states. The limit to forcefully alter the status quo and the associated political risks disadvantage the challenger and help entrench the status quo. These points are best illustrated by the India-Pakistan case. They are also evident in a limited manner in the conflict across the Taiwan Strait.

I begin with the basic observation that the attempts by Pakistan to alter the territorial status quo in Kashmir and by China to force a particular political outcome in Taiwan through the threat and use of force failed. Jervis's qualification of his argument and Kapur's extension of that argument may explain why Pakistan resorted to military action in 1999, but cannot account for the failure and implications of that action. To begin with, the relatively small-scale Pakistani military infiltration, even if successful, could not have substantially altered the territorial status quo in Kashmir, although it could have set a precedent for further "salami tactics." In the end, it did not bring about even a minor change in the territorial status quo. On the contrary, the outcome of the military action helped entrench the territorial status quo. India responded firmly to the military intrusion. It defeated and compelled the withdrawal of the Pakistani infiltration force. After 
initial denials, Pakistan acknowledged that regular troops undertook the military intrusion and eventually had to wirhdraw that force. The risk of escalation cut both ways. It constrained India's military options, but it also circumscribed Pakistan's response to the Indian military reaction. Pakistan could not openly support its forces in Indian-held Kashmir or escalate the war. By strictly limiting its military response to territory under its control, India gave credence to and legitimated the LoC. And since the conflict, New Delhi has insisted that although it is open to new thinking on the Kashmir issue, it would not condone altering the LoC. International support for this position has since increased.

India emerged from the conflict as a responsible status quo power, whereas Pakistan"s "adventurist" behavior further tarnished its shaky international image. The rise of Islamic extremism in Pakistan, Islamabad's support for the Taliban regime when that regime was in power in Afghanistan, the wide and substantial damage done by the A. Q. Khan network, military authoritarianism, and political instability, among others, had raised concerns about Pakistan as a viable state and a responsible nuclear weapon state. The 1999 adventure added to these concerns. The inability to bring about even a minor change in the territorial status quo and the grave risks associated with a limited conflict under nuclear conditions appear to have led to a sober assessment of the role of nuclear weapons in this dyad. The net effect of nuclear weapons has been to enhance deterrence dominance and entrench the political and territorial status quo.

The Taiwan case is less instructive as the role of nuclear weapons is implicit, and there has not been a severe crisis. Further, China was not trying to alter the territorial status quo through force but to influence the political situation on the island in a desired direction. Seeking to affect the outcome of the Taiwan presidential elections in 1995, China fired missiles in the vicinity of the island. That effort failed. Not only did the result of the election go against the outcome desired by Beijing, the United States responded in a firm manner by deploying two aircraft carriers and warning China that it would not tolerate intimidation and forceful change in Taiwan's status. China refrained from escalating the military conflict out of concern that it could not achieve conflict escalation dominance and that escalation would risk bringing nuclear weapons more directly into the conflict. Although China has not renounced the use of force and continues to build up its missile and amphibious capabilities, that crisis highlighted the dangers and drawbacks of relying on the force option (including the negative consequences for its image as a responsible rising power), leading Beijing to deemphasize forceful unification. That incident as well as the public discussion in China of the merits of its no-first-use (NFU) policy and the advocacy in certain Chinese quarters for using nuclear weapons in a war-fighting role in the event of a military conflict across the Taiwan Strait has also chastened the United States. Since the I995-96 crisis, the emphasis in both China and the United States has been on preserving the status quo. Reversing its earlier strong support, the Bush administration leaned heavily on the Chen administration in Taiwan not to take any unilateral action that would alter the status quo. In the India-Pakistan case and in the conflict across the Taiwan Strait, nuclear weapons have further reduced the prospects for military victory and strengthened the status quo and stability.

\section{The Domino Effect Has Not Materialized}

It will be useful at this juncture to address more directly the set of instability arguments advanced by certain policy makers and scholars: the domino effect of new nuclear weapon states, the probability of preventive action against' new nuclear weapon states, and the compulsion of these states to use their small arsenals early for fear of losing them in a preventive or preemptive strike by a stronger nuclear adversary.

On the domino effect, India's and Pakistan's nuclear weapon programs have not fueled new programs in South Asia or beyond. Iran's quest for nuclear weapons is not a reaction to the Indian or Pakistani programs. It is grounded in that country's security concerns about the United States and Tehran's regional aspirations. The North Korean test has evoked mixed reactions in Northeast Asia. Tokyo is certainly concerned; its reaction, though, has not been to initiate its own nuclear weapon program but to reaffirm and strengthen the American extended deterrence commitment to Japan. Even if the U.S.-Japan security treaty were to weaken, it is not certain that Japan would embark on a nuclear weapon program. Likewise, South Korea has sought reaffirmation of the American extended deterrence commitment, but has firmly held to its nonnuclear posture. Without dramatic change in its political, economic, and security circumstances, South Korea is highly unlikely to embark on a covert (or overt) nuclear weapon program as it did in the 1970 . South Korea could still become a nuclear weapon state by inheriting the nuclear weapons of North Korea should the Kim Jong II regime collapse. Whether it retains or gives up that capability will hinge on the security circumstances of a unified Korea. The North Korean nuclear test has not spurred Taiwan or Mongolia to develop nuclear weapon capability.

The point is that each country's decision to embark on and sustain nuclear weapon programs is contingent on its particular security and other circumstances. Though appealing, the domino theory is not predictive; often it is employed to justify policy on the basis of alarmist predictions. The loss of South Vietnam, for example, did not lead to the predicted domino effect in Southeast Asia. In fact the so-called dominos became drivers of a vibrant Southeast Asia and brought about a fundamental transformation in that subregion (Lord 1993, 1996). In the nuclear arena, the nuclear programs of China, India, and Pakistan were part of a security chain reaction, not mechanically falling dominos. However, as observed earlier the Indian, Pakistani, and North Korean nuclear tests have thus far not had the 
domino effect predicted by alarmist analysts and policy makers. Great caution should be exercised in accepting at face value the sensational predictions of individuals who have a vested interest in accentuating the dangers of nuclear proliferation. Such analysts are now focused on the dangers of a nuclear Itan. A nuclear Iran may or may not have destabilizing effects. Such claims must be assessed on the basis of an objective reading of the drivers of national and regional security in Iran and the Middle East.

\section{Declining Probability of Preventive Military Action} in East and South Asia

The prospect of military action to destroy nuclear weapons and facilities in East and South Asia has declined markedly. The Soviet Union contemplated preventive military action against China's nuclear facilities in 1969, but the United States refused to support such action. Several years ago there was concern that India might attack Pakistan's nuclear installations. Even if this was a serious possibility, its probability has declined sharply. The two countries entered into an agreement not to attack each other's nuclear facilities. This agreement held even during the crisis situations in the 1999-2002 period. Since then, India and Pakistan have taken additional measures to prevent an accidental outbreak or escalation of conflict.

More germane to the contemporary context is the emphasis in the U.S. 2002 Nuclear Posture Review on offensive military action against rogue states. The United States seriously contemplated a preventive strike against North Korea's nuclear weapon facilities during the first nuclear crisis on the Korean peninsula in 1993-94 (Perry 2006). And the George W. Bush administration threatened preventive action against North Korea during its first term, ${ }^{3}$ However, that policy has lost traction and has no support among states in Northeast Asia, including U.S. allies. Neighboring countries oppose any preventive strike, fearing that it could result in a general war that would have negative consequences for their own national security and regional stability. Although the United States has the military capability to undertake such an action it is unlikely to act without the support of its regional allies. The force option is still on the table, but the approach to resolve the North Korean nuclear problem has decidedly shifted to the diplomatic arena.

In contrast, preventive military action against presumed nuclear facilities has been more common in the Middle East. Israel undertook a preventive strike on Iraq's Osirak reactor in I98I. The United States invaded Iraq in 2003 on the grounds that Saddam Hussein was developing weapons of mass destruction. It is now confirmed that on September 6, 2007, Israel attacked an alleged nuclear facility in Syria supposedly supplied by North Korea. In addition to warning Syria, there is speculation that this strike was intended as a message for North Korea and Iran. For some time now, there has been speculation that the United Statés or Israel might carry out preventive military action against Iran. In recent times the fear of a nuclear Iran has been compounded by presumed Iranian interference in Iraq, the implosion of that country, and the perceived development of an Irancentered alignment in the Middle East that would be detrimental to the interests of the United States, its Arab allies, and Israel. Speculation that the United States is contemplating a military strike on Iran waxes and wanes, with Tehran warning of severe consequences for the United States and Israel.

Certainly the United States and Israel have the military capability to carry out a preventive strike on Iran's nuclear facilities (Logan 2006; Raas and Long 2007). However, such action would have to cross several hurdles and success is uncertain. Iran's nuclear complex is large, carefully concealed, and spread throughout the country. The availability of accurate intelligence and the political repercussions of such an attack are primary limiting factors. The ongoing wars in Afghanistan and Iraq are limiting factors as well. A directed military strike against critical nuclear facilities might not strain American military capability, but a full-scale invasion of Iran to bring about regime change would. The political, diplomatic, economic, and military costs of such a war would be high for the Unired States. Although support for preventive action appears to have increased among certain Western allies, and the Arab allies of the United States might not object, there would be little international support in other regions or domestic support in the United States. Even if it does not carry out a military strike, Washington might not object to an Israeli preventive action. It has been reported that Tel Aviv and Washington shared intelligence before the Israeli strike against the Syrian facility. From the preceding discussion it appears that preventive military strikes are still a possibility in the Middle East. Compared to the rest of Asia, there are far fewer checks and balances in the Middle East. Offensive use of force continues to be important in that subregion.

\section{Incentive for Early Use and Instability: Not an Empirical Reality}

It has been argued that states with small or nascent nuclear arsenals might have strategic incentive to use them early in a conflict to secure a military advantage in an impending full-scale war or to prevent the crippling of their nuclear arsenals in the event of a preventive strike. Without survivable nuclear forces, these considerations would encourage launch-on-warning postures that could produce crisis situations and undermine stability. Park and Lee (Chapter 9 of this volume) discuss this theme in relation to North Korea. Although uncertain how this theoretical possibility might materialize, they posit that North Korea's nuclear armaments will generate continuous crises and threats to peace on the Korean peninsula. That North Korea's quest for nuclear weapons and the American responses have generated crisis situations and may do so in the future is not the issue. The question 
is whether nascent and small nuclear weapon states will adopt early-launch postures that produce crisis and undermine stability. There is little empirical evidence to support such a claim.

In the abstract, it would be illogical for a nascent or small nuclear power to adopt such a posture against a much superior adversary, as for example in the standoff between North Korea and the United States. Even if North Korea were to inflict substantial damage on the United States or its allies, it is unclear what coercive value would accrue to it. It is almost certain, though, that it would not survive a massive retaliatory strike by the United States. An early use posture can only be rationalized on the basis of an irrational regime, as has been the case with North Korea. However, if North Korea develops a partially survivable nuclear force, early use could have some value; but still such use is likely to be deterred by the possibility of massive retaliation and destruction by the more powerful adversary. Early use postures may make more sense between powers of roughly equal capability with partially survivable nuclear forces. However, evidence from the India-Pakistan dyad, which has a relatively longer nuclear history, does not support this abstract possibility. Despite Pakistan's refusal to embrace an NFU policy and its attempt to exploit the risk of escalation to nuclear war, Islamabad has not opted for an early use posture (see Khan and Lavoy, Chapter 7 of this volume). India, which is committed to an NFU policy, has also not adopted an early use posture. As Devin Hagerty (I998) points out, despite the tensions between them, both countries have taken unilateral and bilateral measures to avoid early use. Deterrence, not early use, characterizes their nuclear postures.

Evidence from Asia offers little support for the instability arguments. On the contrary, the claim that nuclear weapons have thus far contributed to security and stability rests on a relatively stronger empirical foundation. Stability has also been enhanced by the further circumscription due to nuclear weapons of the role of force in Asian international politics.

\section{Reinforcing the Circumscription of Force}

In $2003, \mathrm{I}$ argued that the role of force in Asian international politics was becoming circumscribed (Alagappa 2003b). I attributed the declining salience of force to several developments: the general acceptance in Asia of the prevailing political and territorial status quo, which makes conquest and domination unacceptable and reduces the need for a forceful defense of a state's core interests; an increase in the political, diplomatic, and economic cost of using force in a situation of complex interdependence; and the impracticality of resolving conflicts through force. These considerations reduce the need for the offensive role of force, leaving defense, deterrence, and assurance as the primary missions of armed forces in the region. Over the past three decades, the use of force has been limited to border clashes, militant insurgencies, and occasional clashes at sea, where the danger of escalation is low. A major war could still occur, but the probability has declined dramatically since the early phase of the Cold War, when Asia was the site of several large-scale wars.

Nuclear weapons reinforce the declining salience of the offensive role of force in the Asian security region and increase the importance of deterrence, defense, and assurance. The logic of the enormous destructive power of nuclear weapons and the lack of defense against them also applies to Asia. None of the key regional conflicts can be resolved through the use of force, including conventional military force. The danger of escalation limits the offensive role of conventional military force among nuclear weapon states. The salience of deterrence and defense, already on the rise in the context of wide acceptance of the status quo, is now becoming entrenched. Asian states are becoming defensive realists. Nuclear weapons make nuclear deterrence and conventional defense the dominant strategies. Despite the U.S. effort to build a strategic defense system, deterrence dominance, for reasons advanced in earlier discussion, is likely to continue for the foreseeable future. Target nuclear weapon states can and will take measures to increase the robustness of their strategic deterrent forces. In situations of stark asymmetry, limited strategic defense may make a difference and make offensive use of force under nuclear conditions more attractive. However, it is unlikely to eliminate all uncertainty; continued caution is likely counsel against offensive military action.

Fear of escalation to the nuclear level and the desire to be viewed as a responsible player by the international community appear to have constrained India's military options in 1999. A similar fear constrains Chinese and American options across the Taiwan Strait, and American options on the Korean peninsula. The military, political, diplomatic, and economic costs of using force, especially nuclear force, is very high among nuclear weapon states. Nuclear weapons strengthen the growing trend in the region that emphasizes conventional defense, nuclear deterrence, and political assurance.

\section{Modifying Effect on System Structure and Dynamics}

Nuclear weapons have not fundamentally altered system structure, which is defined by the overall distribution of power (that depends on several attributes, including but not only military power) in the system. Nor have they altered the patterns of amity and enmity in the Asian security region, which are a function of threat perceptions rooted in political disputes, competition for international position and influence, historical animosities, and other factors. However, nuclear weapons have strengthened weaker powers and in certain situations have intensified or ameliorated the intensity of threat perception. These consequences have had a leveling effect and affected security dynamics in certain relationships. 


\section{Strengthening Weaker Powers}

Nuclear weapons strengthen weaker powers by canceling or mitigating the effects of imbalance in conventional and nuclear weapon capability and thereby reducing their strategic vulnerability. By threatening nuclear retaliation and catastrophic damage in the event of large-scale conventional or nuclear attack, and exploiting the risk of escalation to nuclear war, weaker powers with nuclear weapons constrain the military options of a stronger adversary. This is most evident in the India-Pakistan dyad but also in the China-U.S. and North Korea-U.S. dyads.

Pakistan is much weaker than India in several dimensions of national power, including conventional military capability. It suffered defeats in two of the three conventional wars it fought with India in the prenuclear era, with the I97I war resulting in humiliating defeat and dismemberment. In the nuclear era, which dates from the late I980s, Islamabad has been able to deter India from crossing into Pakistan proper and Pakistan-controlled Kashmir even in the context of Pakistani military infiltration into Indian-controlled Kashmir in 1999. India did not follow through with the limited-war option in 200I-02 because of the grave risk it entailed. India was also forced in part by the risk of nuclear war to engage in a comprehensive dialogue to settle disputes between the two countries, including the Kashmir conflict. Pakistan's nuclear arsenal has blunted the potency of India's large conventional military force. Although it has not canceled out all the consequences of the large power differential between the two countries, it has had significant constraining impact with carry-on effects for subregional security structure and dynamics.

China viewed nuclear weapons as a cheap and effective way of counterbalancing the United States and the Soviet Union during different phases of the Cold War (Goldstein 2000). Despite its rapid rise, Beijing still views its relatively small nuclear arsenal as a key means of redressing the huge imbalance in military capability with the United States. A small but modernizing nuclear arsenal has enabled it to limit the coercive consequences of the strategic imbalance and restrain American military intervention in the conflict across the Taiwan Strait. Further, by mitigating the effects of military imbalance, a growing China has been able to exploit its other stronger attributes to enhance its power and influence in Asia. Like China vis-à-vis the United States, India sees it nuclear arsenal as necessary to reduce its strategic vulnerability in relation to China. A much weaker Russia now seeks to compensate for its weakness in conventional military power with its still formidable nuclear arsenal.

The leveling and cautionary effects of nuclear weapons are also evident in the relationship of the weak and isolated North Korea with the vastly superior United States. Although North Korea does not have an operational nuclear arsenal and the United States can destroy that country many times over, the risk of quick and substantial damage to its forces and allies in the region induces caution and constrains U.S. military options. If in the future North Korea develops nuclear weapons and marries them to its missile capability, the risks associated with preventive military action against that country would multiply. Instead of simply suffering the will of the mighty United States, North Korea's nascent capability has provided it with security and bargaining leverage in its negotiations with major powers in the region.

\section{Modifying Effect on System Structure}

The greater potential for internal balancing and the leveling effect of nuclear weapons modify system structure and its effects. In South Asia, for example, having nuclear weapons has enabled Pakistan to militarily counterbalance India and make Indian dominance of that subregion more difficult. Although Pakistan has all along balanced India, conventional balancing became more difficult after the dismemberment of Pakistan in I97I and the highly contingent nature of external support. Nuclear weapons enable Pakistan to counterbalance and constrain India's military options in a more sustained manner, relying on its own capability. Likewise, the Chinese nuclear capability has a modifying effect on American dominance. The hegemonic position and influence of the United States in Asia is increasingly constrained by China; nuclear weapons indirectly contribute to this.

At the same time, nuclear weapons in themselves have not fundamentally altered system structure in the Asian security region. The unipolar structure of the present system and the anticipated changes in the distribution of power among states in the Asian security region are consequences of change in the overall national power of states that has several dimensions. Military power is an important component of national power; and, as indicated earlier, having nuclear weapons makes a significant difference in national military capability. However, military power by itself is not a sufficient basis for major power status. Further, without strong political, economic, technological, and demographic foundations, it is difficult to sustain a strong military capability, as demonstrated by the experience of the former Soviet Union. The enormous destructive power of nuclear weapons is important for its modifying effect, but it is less fungible and less relevant in the pursuit of nonsecurity goals. Nuclear weapons add to but are not a sufficient basis of national power.

The present dominance of the United States, the decline in the position of Russia, and the rise of China and India are not due to their nuclear weapon capabilities. U.S. dominance is grounded in its vast lead in several dimensions of power. Although Russia still has a formidable nuclear arsenal, it is not a superpower or even a top-tier regional power in Asia. In fact, the rapid decline of the Soviet Union/Russia from superpower status was due to the fact that it was a one-dimensional (military) power. That lesson has not been lost on China, which 
seeks to develop comprehensive national power (Wu 1998). China has long had nuclear weapons and is slowly modernizing its nuclear arsenal. The rapid and substantial increase in its national power and the apprehension it creates are primarily due to China's sustained high rate of economic growth, which in turn produces the resources for accumulating and exercising international power and influence. Likewise, the rise in the power and status of India is due in large measure to its economic growth and change in foreign policy. Nuclear weapons contribute to but do not account for India's rise. Political stability, economic growth, technological advancement, and human resource potential and development, along with military capability, contribute to international perception and ranking of states.

I disagree with those who discount or sideline the salience of nuclear weapons in the power and prestige of countries in the contemporary era (Paul 1998), but at the same time it is necessary to locate the importance of nuclear weapons in proper perspective. Military power remains an important component of national power. To be taken seriously as a major power with a voice in international security matters, a country must possess substantial military capability. This is reflected in the defense expenditures and policies of all major states and in the quest of Japan to become a "normal" power. Although it has been an economic superpower for more than two decades and has made substantial financial contributions to the peace and security efforts of the United Nations and those of its alliance partner, the United States, Japan has been unable to gain the international status and recognition it desires. It now seeks to develop its conventional military capability so that it can contribute "blood" and not just "treasure" in meeting its international obligations and security treaty commitments and to play a more assertive role in shaping the emerging international security order in Asia and more broadly the world. Although Japan does not seek to acquire nuclear weapons, it would like to institute measures to increase the effectiveness and credibility of the American extended deterrence commitment to Japan. If the U.S. commitment erodes, it is not improbable though not certain that Japan may develop its own nuclear weapon capability.

\section{Exacerbating Some Security Concerns but Not Others}

Nuclear weapons have not fundamentally altered lines of amity and enmity in the Asian security region. The principal effect of nuclear weapons has been their consequence for the intensity of existing animosities, not the creation of new ones except possibly in the Middle East, where a nuclear Iran could substantially alter the subregional lines of enmity. Offensive strategies for the employment of nuclear weapons have intensified existing security dilemmas; but deterrence strategies have not.

Enmity in the India-Pakistan dyad dates to the partition of British India and their conflict over Kashmir and Pakistan's quest for equality with India. Nuclear weapons have both ameliorated and intensified threat perceptions in this dyad. They have mitigated Pakistan's sense of insecurity by constraining India's military options. The large asymmetry in conventional military capability has become less consequential. Nuclear weapons, including Pakistan's first-use strategy, have strengthened deterrence in this relationship. However, Pakistan's policy to exploit the risk of escalation to nuclear war to alter the political and territorial status quo in Kashmir, and India's coercive response to restore the status quo and to demand cessation of Pakistani support for crossborder insurgent movements, intensified both countries' vulnerabilities and threat perceptions, and resulted in crisis situations early in the overt nuclear era. Since then, however, the situation has stabilized. A mixed strategic picture (conflict, dialogue, and negotiations between the two countries, along with other priorities and international pressure) has helped to reduce the threat intensity between them. Recognition of the grave risks associated with offensive strategies under nuclear conditions is a factor as well. Although both countries continue to develop their nuclear and missile capabilities with reference to each other, the anxiety surrounding missile tests and military exercises has declined. Further, the crises precipitated by offensive strategies deepened the security interdependence between the two countries, providing a basis for limited confidence building and arms control measures to prevent unintended escalation of hostilities.

North Korea's quest for nuclear weapons heightened existing security concerns in the United States, Japan, and South Korea, all of which were already in adversarial relationships with that country. U.S. threats of preventive action intensified North Korea's threat perception, providing additional rationale and momentum to its nuclear quest. The net effect has been to intensify threat perceptions in the U.S.-North Korea and North Korea-Japan dyads and to a lesser degree in the North Korea-South Korea dyad. This has contributed to strengthening the security ties between the United States and its allies in Northeast Asia. For different reasons, China too became concerned about North Korea's nuclear program. That program, and particularly the 2006 North Korean nuclear test, heightened Chinese sensitivity to the negative consequences for security and stability in Northeast Asia and for China. These included the increased possibility of American preventive military action to destroy North Korea's nuclear facilities, regime collapse and turmoil in a neighboring country, massive refugee outflows, Japanese involvement on the Korean peninsula, and the further strengthening of U.S.-Japan-Sourh Korea security relations. A nuclear North Korea could also complicate the U.S. focus of China's nuclear strategy. Beijing began to view the North Korean nuclear program as a serious security problem and became active in trying to defuse it by hosting the Six-Party Talks. Such involvement would also have diplomatic gains for China on several fronts and make it a key player in managing security in Asia. 
Iran's nuclear quest has created apprehensions in Israel and certain Arab countries in the Middle East. A nuclear Iran is likely to intensify the Israel-Iran line of entmity and bring about change in Israel's nuclear posture, making nuclear weapons more prominent in Middle East security. The animosity between Iran and the Arab states may also intensify, while that between Israel and the Arab states could become tempered.

A mong the major powers, nuclear weapons have created apprehensions but not fundamentally altered the basis and nature of their security interaction, which is characterized by cooperation and conflict. The vastly superior American nuclear arsenal, and especially Washington's emphasis on offensive and defensive strategies, have raised concerns in Beijing and Moscow. Talk of U.S. nuclear primacy with a disarming capability created disquiet in these countries. The United States clarified that its offensive and defensive strategies are specifically directed at rogue states, and there is increasing doubt that the United States could develop effective strategic defense capabilities against China and Russia. Nevertheless, these countries can be expected to strengthen their strategic deterrent forces and increase their policy options in relation to the United States. At the same time, China has not abandoned its minimum deterrence strategy to engage in direct nuclear competition with the United States. The Chinese response has been deliberately indirect and muted. By retaining a posture of dynamic minimum deterrence and an NFU policy while continuing to modernize its nuclear force, China seeks to prevent deterioration of its security relations with the United States. In the case of Russia, its strong opposition to the U.S. ballistic missile defense deployment in Eastern Europe and its suspension of the Conventional Forces in Europe Treaty further strained U.S.-Russia relations. However, Russia has not articulated a nuclear strategy to directly challenge or compete with the United States. The United States also does not appear to have altered its view of not treating Russia as an enemy state.

Nuclear weapons have not substantially altered Sino-Indian security interaction, which appears to be proceeding on dual tracks: engagement and cooperation along with mutual suspicion and quiet competition. Although China condemned the Indian nuclear tests, and India is concerned about the strategic imbalance, neither country has emphasized nuclear weapons in their relationship. India seeks to build a robust deterrent against China, but it has not pursued this goal with urgency. China too has deemphasized its nuclear force in relation to India. The low-key general deterrence postures of both countries reflect their common desire to improve bilateral relations.

Evidence from Asia supports the general proposition that arms per se do not create insecurity, but strategies for their employment may intensify or ameliorate insecurity. And nuclear weapons may modify but do not fundamentally alter the pattern of security interaction. The modifying effect of nuclear weapons on system structure is evident in alliances and alignments in the Asian security region.

\section{Mixed and Complicating Effect on Alliances and Alignments}

Alliance formation and sustenance is a function of threat perception and balance of military capabilities (Walt 1987 ). The greater potential of nuclear weapons for internal balancing may reduce the need for a small nuclear weapon state to engage in external balancing by allying with a latger nuclear weapon state, but alliances among them can still be forged or sustained on other strategic considerations. A small nuclear weapon state lacking a secure second-strike capability and, fearing nuclear attack by a stronger adversary, for example, may choose to align or ally with a larger nuclear weapon state. Alignment or alliance among nuclear weapon states may also rest on other benefits (such as status, diplomatic and economic gains, and technological transfer). Perceiving a nuclear threat and lacking its own capability, a nonnuclear weapon state may choose to ally with a nuclear weapon state that can extend the deterrence function of its nuclear arsenal. The alliance relationship of a nonnuclear or small nuclear weapon state with a larger one confronts two problems. One is fear of entrapment; the danger of becoming involved in the patron's broader security commitments that may have negative consequences for it. The larger nuclear weapon state also fears entrapment, as its junior partner could draw it into an undesired confrontation with another nuclear weapon state. The second problem - fear of abandonment-is more applicable to a client or junior partner state in an alliance relationship. The fear is that its security interests may be sacrificed in the national interest of the larger state, especially if that state is vulnerable to retaliatory nuclear attack. In sum, nuclear weapons can strengthen and weaken alliances and make their management more complicated. All these effects of nuclear weapons on alliances are visible in Asia.

As observed in Chapter 17, states perceiving existential threats view nuclear weapons as the ultimate security guarantee. In a worst-case scenario, they can rely on their own nuclear deterrent without the fear of abandonment. Nuclear weapons have reduced the salience of external balancing for Israel, Pakistan, and North Korea. Nevertheless, Israel still values close strategic ties with the United States, and Pakistan with China. Israel derives considerable political, diplomatic, strategic, economic, and technological benefits (and incurs some costs) from its close ties with the United States. Its opaque nuclear status is in part due to an understanding reached between Washington and Tel Aviv (Cohen, Chapter 8 of this volume). Pakistan's nuclear weapon capability has not significantly affected its strategic alignment with China, which is grounded in their common concern over India. Islamabad still relies on China for political and diplomatic support, 
assistance with nuclear and missile technology, and economic assistance (Khan and Lavoy, Chapter 7 of this volume). For China, Pakistan is still valuable in constraining rising India's power and influence in and beyond South Asia. Pakistan's strategic independence also permits China to adopt a more neutral position on issues such as the Kashmir conflict and improve relations with India without undermining those with Pakistan.

North Korea has no military ally. Beijing's commitment to the security of North Korea has been reduced significantly in the context of China's modernization drive, dramatic improvement in the PRC and the Republic of Korea's (ROK) relations, and the political transition in North Korea. The growing conception in China of North Korea as a security problem has weakened Beijing's support for the Kim Jong Il regime. However, China does not wish collapse of the North Korean regime and opposes preventive military action against North Korea. Pyongyang's security ties with the Soviet Union terminated with the collapse and fragmentation of that country. Russia provides only conditional diplomatic support. Termination of the alliances with China and Russia, its weakening economic and military position, and diplomatic isolation spurred the imperative for North Korea's self-reliant deterrent capability.

Other nonnuclear weapon states like Japan, South Korea, Australia, and Taiwan that perceive military threats from nuclear armed adversaries have taken a different route: sustaining and strengthening their alliance relationships with the United States. As discussed in Chapter 17, North Korea's nuclear weapon and missile programs and China's modernization of its nuclear arsenal are perceived in Japan as increasing its strategic vulnerability. Rather than seek an independent nuclear weapon capability or reduce the salience of the U.S.-Japan security alliance, the nuclear concern provides an additional incentive for deeper security ties between Japan and the United States (see Green and Furukawa, Chapter 12 of this volume). Tokyo is seeking mechanisms for nuclear dialogue with Washington and for input into U.S. nuclear policy toward Asia to increase the credibility of the American extended deterrence commitment. There is concern that the U.S. may enter into understandings or agreements with China and North Korea that do not take full account of Japan's interests. A fear of abandonment lurks in the background and could become stronger, especially if the United States becomes vulnerable to a nuclear strike by North Korea. For now the emphasis is on strengthening the U.S.-Japan alliance. Tokyo also seeks to enhance strategic relations with other like-minded countries, such as Australia and India.

The North Korean nuclear test also resurrected interest in South Korea to reaffirm the American extended deterrence commitment under the U.S.-ROK security treaty. Through much of its post-World War II history, Seoul was worried about abandonment and the need to firmly bind the United States to South
Korea's security (Choi and Park, Chapter 13 of this volume). Since the early r9gos, however, South Korea has been deeply conflicted over its security alliance with the United States. This was reflected in the security policies of the progressive administrations of Kim Dae Jung and Roh Moo Hyun. Seoul was worried about becoming entrapped in an American preventive military action against North Korea and becoming involved in U.S. global security commitments like that in Iraq. The North Korean nuclear test helped heighten the importance of the U.S. security commitment. And the incoming conservative Lee Myung Bak administration is committed to improving South Korea's ties with the United States and transforming the U.S.-South Korea military alliance into a "Korea-U.S. Strategic Alliance" based on three core principles of "common values, trust, and peace" (Lee 2008). Differences in threat perception, competing goals and interests, and future burden and responsibility sharing, along with change in the nature of threats, are likely to complicate future management of U.S. alliances with Japan and South Korea. However, the alliances themselves are likely to continue.

The entry of new, "irresponsible" nuclear powers (Pakistan and North Korea) and the changed security environment have raised questions about the earlier Australian rationale for supporting the U.S. nuclear umbrella and Australia's security alliance with the United States (Lyon, Chapter 15 of this volume). However, this largely intellectual doubt does not appear to have affected the U.S.-Australia alliance, which deepened in the wake of $9 / 1$ I and under the John Howard administration. The new Kevin Rudd government seeks closer ties with China and may be less enthusiastic about contributing to U.S. global military ventures, but it is unlikely to substantively alter the close security relationship with the United States.

The fear of abandonment and entrapment are most visible in the Taiwan-U.S. security relationship. The United States is the only and vital security guarantor for Taiwan. However, the U.S. commitment is deliberately ambiguous, implicit, and designed to deter China as well as Taiwan. Taiwan cannot take the U.S. commitment for granted (Wang, Chapter 44 of this volume). Fearing abandonment, it has to continuously work to retain U.S. support. For its part, the United States fears entrapment being drawn into a war situation not of its choosing. Although the United States seeks to deter China, it does not want a major war with that country, especially one that could escalate to the nuclear level. Management of the U.S. commitment to the security of Taiwan has become more complicated with the rise of China; the modernization of its nuclear, missile, and naval forces; and the need for the United States to cooperate with that country on a wide range of issues.

\section{Not a Barrier to Peaceful Conflict Resolution}

The three key conflicts in Asia (on the Korean peninsula, across the Taiwan Strait, and over Kashmir) cannot be settled by force without huge costs. By dramatically 
increasing the speed and scale of destruction that can occur from their use, nuclear weapons have made the barrier to settlement by force prohibitive. In this sense, it is possible to argue that they have helped freeze conflicts. However, nuclear weapons are not a barrier to peaceful settlement. In fact, the impossibility of military victory and the grave risks associated with nuclear war may have led states to alter their immediate goals and explore a diplomatic settlement.

Nuclear weapons constrain Chinese use of force to alter the status quo and achieve its unification goal. Recognizing the risks associated with military action (including possible escalation to nuclear war), the unlikely prospect that the Taiwan conflict will be resolved peacefully to its satisfaction in the foreseeable future, and a belief that the present trend in cross-Strait relations is in its favor, China has in recent years begun to shift its emphasis from unification to preventing Taiwan independence and preserving the status quo. On the Korean peninsula, recognizing the limits and risks of attempting an offensive strategy, the United States altered course to seek a diplomatic settlement of the nuclear problem and other disputes there. In India-Pakistan relations as well, the grave risks associated with the military standoff between the two countries have forced them to explore negotiated settlement of the multiple disputes, including the status and control of Kashmir.

It should be observed here that multiple factors account for the shift in objective (in the Taiwan conflict) and the decisions to enter into dialogue and negotiate diplomatic settlements (of the North Korea and Kashmir conflicts). Limits and risks associated with nuclear weapons are one inducement. Ultimately, the peaceful settlement of these conflicts will hinge on working out compromise agreements. Such compromises become more (or less) possible with domestic political change. Recent government change in Taiwan and Pakistan has created a positive atmosphere for reducing tension and negotiating bilateral agreements to establish stable and peaceful relations in hitherto tension-ridden dyads. The incoming $\mathrm{Ma}$ Ying-jeou administration in Taiwan does not push the independence agenda, desires better relations with China, and is viewed favorably by Beijing. Although the unification issue is unlikely to be resolved soon, the favorable developments are likely to enhance cross-Strait relations and increase Taiwan's security and international space. Likewise, the swing to democratic government in Pakistan may augur well for continuation of the India-Pakistan comprehensive dialogue and movement toward a negotiated settlement. But the presence of spoilers may make even an interim arrangement difficult. In South Korea, change in government may set back North-South relations. Although he favors continued engagement of North Korea, Lee Myung Bak would like to see greater progress on the nuclear issue and greater reciprocity in North-South relations.

It is pertinent to observe here that nuclear weapons may have helped freeze the Cold War confrontation, but they did not prevent its termination. That confron- tation came to an end with change in government in the former USSR. Gorbachev's accession to the top position in the Soviet Communist Party and his reform policies were crucial in ending the Cold War and in the eventual dissolution of the USSR. Although China was not locked into a nuclear confrontation, the transition from Mao Tse Tung to Deng Xiao Ping and the latter's open-door policy and modernization program were crucial in changing China's international orientation. The general point is that resolution of disputes hinges on willingness to make deep political compromise; this can only come about through fundamental change in policy, which in turn becomes possible with idea-driven change in government. Nuclear weapons are instruments of policy and need not be a barrier to settlement of political disputes.

\section{Forging a New Nuclear Order}

The Cold War nuclear order emerged in the context of the largely Eurocentric Soviet-American confrontation. Although Israel had a serious covert nuclear weapon program and India had conducted a peaceful nuclear explosion in 1974, China was the only non-Western country acknowledged as a nuclear weapon state. The nuclear arsenals of the United States, the Soviet Union, Britain, France, and China were considered legitimate. ${ }^{4}$ That nuclear order was founded on the twin concerns of sustaining deterrence between the two superpowers and preventing additional proliferation (Walker 2007). The primary concern was the deterrence strategies of the United States and the Soviet Union and their implications for international security and stability. Arms control measures were designed to prevent the unintended outbreak and escalation of hostilities between them, to manage crisis, and to advance stability in their strategic interaction. There was less worry over the security strategies of the second-tier nuclear weapon states and their implications. The primary effect of the Non-Proliferation Treaty (NPT) that formed the second pillar of the Cold War nuclear order was to legitimize the discrimination embodied in that Treaty and to prevent additional proliferation by denying material and technology to new aspirants, imposing sanctions on them, and delegitimating new nuclear weapon states. It served the strategic interests of the five nuclear weapon states and ranked below the demands of their national security.

Asia was a sideshow in that order. Policies, strategies, and agreements reached in a Eurocentric context were imposed on Asia. The implications for Asia were often an afterthought. The Cold War order is out of sync with present realties; some assert that it is broken and that a "new" nuclear order has to be constructed (Roberts 2007). A new nuclear order must center on the Asian security region, which has six nuclear weapon states (six including Israel; seven if North Korea is included) and which has become a core world region with potential to emerge as the central region of the world in the twenty-first century. As the findings of this 
study highlight, the nuclear situation in Asia today is dramatically different from that in the Cold War era. Deterrence is still the dominant strategy for employing nuclear weapons, but it operates in a condition of asymmetry and mostly with small nuclear forces. Nuclear weapons have far-reaching implications, but they are not in the forefront as they were in the Cold War confrontation.

\section{Elements of a New Nuclear Order}

A new order should take account of the changed strategic realities; the centrality of Asia; and the "new" roles, strategies, and outcomes of nuclear weapons, and not simply seek to continue to impose treaties and regimes that were negotiated in a different context. Further, it must be flexible enough to accommodate new nuclear powers. In an earlier period, the nuclear order did accommodate the new nuclear weapon states of the Soviet Union, China, Britain, and France. The attempt to freeze that order resulted in several undeclared nuclear weapon states outside the system. The effort in 1995 to close loopholes and permanently freeze the discriminatory nonproliferation regime compelled India, followed by Pakistan, to openly declare their nuclear weapon status. In addition, fear of U.S. military action accelerated the nuclear program of North Korea and that of Iran. The new nuclear order must address five issues: It must $(r)$ sustain deterrence in new conditions and discourage offensive roles and strategies, (2) be capable of accommodating new nuclear weapon states, (3) address the security concerns of potential candidates to prevent further spread of nuclear weapons, (4) prevent proliferation to nonstate actors, and (s) support the peaceful use of nuclear energy with adequate safeguards.

Sustain Deterrence in New Conditions and Discourage Offensive Strategies. As discussion in Chapter 17 highlighted, deterrence continues to be the dominant strategy for employment of nuclear weapons, but it now operates primarily in a condition of asymmetry with mostly small nuclear forces. The nuclear order must support measures to strengthen deterrence stability in the new condition and discourage capabilities and strategies that can undermine security and stability.

Accommodate New Nuclear Weapon States. The nuclear order in the 1950s and t960s did accommodate change by bringing on board new nuclear weapon states. The U.S.-India nuclear deal must be seen in this light. It is an attempt to bring a rising India into the nuclear order with due consideration of its strategic interests and of nonproliferation concerns. This effort cannot be viewed solely or even primarily through the nonproliferation lens. A rigid nonproliferation stance would gradually widen the gap between the formal nuclear order and reality and over time make the formal order largely irrelevant. In due course, country-specific arrangements would have to be worked out for Pakistan and Israel as well. An incremental approach that accommodates change with emphasis on responsible behavior would create a more stable and inclusive nuclear order that can strengthen security and stability.

Slow the Spread by Addressing Demand and Supply. A continuing thrust of the new nuclear order must be to slow the further spread of nuclear weapons by addressing the security concerns of potential nuclear weapon states. One may question why this is an important concern in light of the conclusion of this study that nuclear weapons have thus far contributed to security and stability. My response is as follows. I am not arguing that more is better and that any state that wants nuclear weapons should be able to get them. My argument is that nuclear weapons have contributed to security and stability in the Asian security region. The "new" nuclear weapon states (India, Israel, and Pakistan) acquired the capability over a prolonged period. All three countries believed that nuclear weapons were essential for their security. India and Pakistan were denied technologies, faced sanctions during the covert and overt periods, and incurred high costs in persevering with their quests. Similarly, North Korea and Iran are now confronting sanctions and technology denials. Their nuclear weapon programs may or may not move forward. My point is that if a country strongly believes it needs nuclear weapons for its security, it will persist in that quest and ultimately succeed. At that point the international community has little choice but to accept that country as a nuclear weapon state. The prolonged acquisition period permits adjustments among relevant states. Thus it is still necessary to be concerned with the spread of nuclear weapons to limit it to those countries that consider them vital, are willing to incur high costs, overcome international opposition, and are capable of producing their own weapons and missiles. In the process, the international community should make a serious effort to address the security concerns of such countries (the demand side of the proliferation equation) to obviate the need for these "ultimate" weapons.

In this regard, the U.S. security alliances with Japan, South Korea, and Australia, and its extended deterrence commitments to them, are important in assuaging their security concerns and preventing their pursuit of independent nuclear options. To make its security guarantee even more credible, the United States may have to explore country-specific arrangements. China's continued deemphasis on nuclear weapons in its relations with Japan would also help prevent Japanese pursuit of the nuclear option. In relation to North Korea and Iran, the United States is a prime driver of their quest for nuclear weapons. Washington considers them "bad guys." This they may be, but not addressing their security concerns drives them into a corner from which they see nuclear weapons as their savior. With the failure of its earlier policy, the Bush administration switched to a diplomatic approach that addresses the political, security, and economic concerns of North Korea in an arrangement that would progressively dismantle that country's nuclear weapon capability. 
It is premature to draw any firm conclusions from the North Korean case. Progress has been limited and episodic and could take several years, and success is not guaranteed. But a diplomatic approach that addresses the security concerns of the state pursuing a nuclear weapon capability is likely to be more productive than an approach that stresses isolation, denial, and sanctions. Carrot and stick must go together. Despite the ongoing effort, the international community may have to accept and come to terms with a nuclear North Korea. A determined state cannot be prevented from acquiring nuclear weapon capability. However, the process can be made onerous and costly. Military action that brings about regime change may "permanently" stop the program, but regime change may lead to even worse problems. Iraq is a classic recent example. Nonproliferation is not the only objective. National and regional security and stability are as important if not more important. These objectives and national self-interest appear to drive the Chinese approach to the North Korean nuclear problem. The nuclear nonproliferation regime, if it is to remain relevant, must address both demand and supply. It must also accommodate gray zones rather than insist on black-and-white outcomes.

Prevent the Spread to Nonstate Actors. Another thrust of a new nuclear order must be to prevent the spread of nuclear material, technology, and weapons to nonstate groups and organizations. Nuclear weapons in the hands of nonstate actors threaten both specific states and the entire international system. Countries that provide sanctuary to terrorist groups should be legitimate targets for military action by aggrieved states and the international community. The international community has taken several measures to prevent the spread of nuclear material, technology, and weapons to nonstate actors. Based on a 2002 report by the International Atomic Energy Agency (IAEA 2002), several international instruments have been adopted. These include the Code for Conduct for the Safety and Security of Radioactive Sources and the U.N. General Assembly's International Convention for the Suppression of Acts of Nuclear Terrorism adopted in 2005 (IAEA 2005). The U.N. Security Council Resolution I 540 adopted in 2004 calls on states to strengthen their nuclear safeguards and prohibits them from transferring nuclear capabilities to potentially dangerous nonstate actors. In addition, U.N. Security Council Resolution 1373 adopted in 200 I called on states to become parties to international conventions relating to terrorism. The United States has also initiated several measures, including the Proliferation Security Initiative. The challenge now is to bring more states on board and to implement the various conventions and initiatives. Preventing nuclear terrorism requires sustained vigilance, the development of additional countermeasures, and effective implementation.

Facilitate Development of Nuclear Energy with Adequate Safeguards. The final thrust of the "new" nuclear order should facilitate peaceful use of nuclear power to meet rising energy demand, with adequate safeguards to prevent noneconomic use.
The high price and polluting effects of fossil fuels, as well as the concern that known reserves may be inadequate to meet the growing energy demand, have generated much interest in nuclear energy. To meet the growing demand, international governance will be required to support investment and trade in nuclear energy and to institute sufficient controls to prevent the spread of nuclear weapon capability (Sokolski 2007).

The five issues discussed above that have to be addressed by a new nuclear order are not necessarily complementary. Competing demands are likely to make the forging of a new nuclear order more difficult. Grand schemes will be difficult to design, gain acceptance, and implement. Piecemeal and ad hoc.measures are more likely. Although some aspects may still be relevant, any effort to freeze or restore the Cold War nuclear order wholesale is likely to fail.

\section{Concluding Thoughts}

Asia and the world are entering new strategic and nuclear environments that are dramatically different from those of the Cold War. Though not in the forefront as in the Cold War confrontation, this study has argued that nuclear weapons continue to be important. They cast a long shadow that informs in fundamental ways the strategic thinking, policies, strategies, and interaction of major powers and their key allies. Modernizing their arsenals and building new capabilities, old and new nuclear weapon states envisage new roles and strategies for nuclear weapons in the context of the security challenges they confront. Some states view nuclear weapons as crucial for survival; others see them as a relatively inexpensive way of competing with and deterring stronger adversaries; some see them as insurance to avoid blackmail and cope with strategic uncertainty; and as the world's sole superpower, the United States seeks to employ nuclear weapons and construct a nuclear regime to sustain a U.S.-led global order.

A major conclusion of this study is that deterrence dominance is likely to continue, and deterrence is likely to be the primary role and strategy for the employment of nuclear weapons in the foreseeable future. However, deterrence today functions in a condition of asymmetry and mostly with small nuclear forces. It is further complicated by the development of offensive capabilities and strategic defense. Another important conclusion is that thus far nuclear weapons have contributed to peace and stability in the Asian security region by assuaging national security concerns and reinforcing the circumscription trend in the region on the role of force. Although destabilizing consequences can be imagined, these have been rare and confined to early stages in the acquisition and operationalization of capabilities and strategies. By highlighting the risks and dangers associated with certain roles and strategies, crisis situations have contributed to a more sober assessment of the roles and limitations of nuclear weapons. 
These and other observations advanced in this study run counter to some conclusions reached during the Cold War and differ from prevailing conventional wisdoms. It is crucial to reexamine and refine "old" ideas, concepts, and strategies as well as develop "new" ones relevant to the contemporary nuclear era. This study has identified some baseline national nuclear roles and strategies and explored their regional security implications. The propositions advanced here, however, require further development, refinement, and even reformulation. The meaning, content, and operationalization of the various strategies of deterrence, including the required force levels, for example, require detailed inquiry. How to advance deterrence stability in a condition of asymmetry and small nuclear forces is another important issue to explore. Ensuring the effectiveness and credibility of extended deterrence is another. Having developed a comparative understanding of the roles of nuclear weapons in national security strategies of relevant states and their regional security implications, it is now opportune and necessary to embark on more in-depth work on these issues. Such work must be grounded in the changing political and strategic conditions in Asia and accord due consideration to developments in defense science and technology. It is also important to develop a knowledge community on the subject, especially in Asia, and to foster cross-country and regional dialogues to develop a common discourse and understanding. My hope is that this study provides a foundation for these and other undertakings on the subject of nuclear weapons and security in twenty-first-century Asia.

\section{Notes}

I. For contending explanations of the long peace, see Kegley (199r).

2. Many Western leaders made statements to this effect after the Indian and Pakistani nuclear tests in 1998. See, for example, Clinton (1998)

3. William Perry, a former defense secretary who handled the $1993-94$ nuclear crisis on the Korean peninsula, recommended a military strike to stop the North Korean test of a long-range missile. See Carter and Perry (2006).

4. Mohamed ElBaradei (2006: A23) states that "under the NPT there is no such thing as a 'Iegitimate' or 'illegitimate' nuclear weapon state." The recognition of five states as holders of nuclear weapons was regarded as a matter of transition. The NPT does not confer permanent nuclear weapon status on the five countries.

\section{References}

Alagappa, Muthiah.2003a. "Introduction: Predictability and Stability Despite Challenges. In Asian Security Order: Instrumental and Normative Features, ed. Muthiah Alagappa, pp. 1-32. Stanford, Calif.: Stanford University Press.

2003b. "Managing Asian Security: Competition, Cooperation and Evolutionary Change." In Asian Security Order: Instrumental and Normative Features, ed. Muthiah Alagappa, pp. 571-608. Stanford, Calif.: Stanford University Press.

Buzan, Barry, and Gerald Segal. 1994. "Rethinking East Asian Security." Survival 36 (2): $3-2 \mathrm{I}$.
Carter, Ashton B., and William J. Perry. 2006. "If Necessary, Strike and Destroy: North Korea Cannot be Allowed to Test This Missile." Washington Post, June 22: A29.

ElBaradei, Mohamed. 2006. "Rethinking Nuclear safeguards." The Washington Post, June 14: A23.

Clinton, William. 1998. Rernarks on the Patients Bill of Rights. May 28, r998. Available at http://www.presidency.uesb.edu/ws/index.php?pid $=56039 \& s t=\& s t r=$.

Feaver, Peter. 1992-93. "Command and Control in Emerging Nuclear Nations." International Security 17 (3): $160-87$.

- T993. "Proliferation Optimism and Theories of Nuclear Operations." Searrity Studies $2(3 / 4)$ : I59-9I.

Friedberg, Aaron L. 1993-94. "Ripe for Rivalry: Prospects for Peace in a Multipolar Asia." Intemational Security i8 (3): $s-33$.

Gaddis, John Lewis. 1992. The United States and the Cold War: Implications, Reconsiderations, Provocations. New York: Oxford University Press.

Goldstein, Avery. 2000. Deterrence and Security in the Twenty-first Century: China, Britain, France, and the Enduring Legacy of the Nuclear Revolution. Stanford, Calif: Stanford University Press.

Hagerty, Devin T. 1998. The Consequences of Nuclear Proliferation: Lessons from South Asia. Cambridge, Mass.: The MIT Press.

International Atomic Energy Agency (IAEA). 2002. Protection Against Nudear Terrorism: Specific Proposals. Available at http://www.iaea.org/About/Policy/GC/GC49/Documents/ gc49-I7.pdf.

2005. Nuclear Security: Measures to Protect Against Nuclear Terrorism: Progress Report and Nuclear Security Plan for 2006-9. Available at http://www.iaea.org/About/Policy/ $\mathrm{GC} / \mathrm{GC}_{4} 9 /$ Documents/gc49-17.pdf.

Jervis, Robert. 1988. "The Political Effects of Nuclear Weapons." International Security, 13, Fall: $28-38$.

1989. The Meaning of the Nuclear Revolution: Statecraft and the Prospect of Armageddon. Ithaca, N.Y: Cornell University Press.

Kapur, S. Paul. 2006. Dangerous Deterrent: Nuclear Weapons Proliferation and Conflict in South Asia. Stanford, Calif.: Stanford University Press.

Kegley, Charles W. 199I. The Long Postwar Peace: Contending Explanations and Projections. New York: Harper Collins.

Lee, Myung Bak. 2008. "Address by H.E. Lee Myung Bak, 17th President of the Republic of Korea." New York: Korea Society. Available online at http://www.koreasociety .org/dmdocuments/20080415-LeeMyungBak-English.pdf.

Logan, Justin. 2006. The Bottom Line on Iran: The Costs and Benefits of Preventive War versus Deterrence. Washington, D.C.: CATO Institute, Policy Analysis No. 583 .

Lord, Winston. 1993. "A New Pacific Community: Ten Goals of American Policy." Opening Statement of Confirmation Hearings: East Asian and Pacific Affairs. Washington, D.C.: Subcommittee of the Senate Foreign Relations Committee. Available at http://

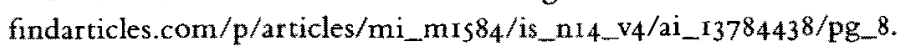

- I996. "U.S. Relations with Indonesia." Washington, D.C.: Statement before the Subcommittee on East Asian and Pacific Affairs of the Senate Foreign Relations Committee, September I8. Available at http://dosfan.lin.uic.edu/ERC/briefing/dispatch/ I996/html/Dispatchv7no38.html. 
Morgan, Patrick M. 2003. Deterrence Now. Cambridge, UK: Cambridge University Press. Mueller, John. 1988. The Essential Irrelevance of Nuclear Weapons: Stability in the Postwar World." International Security, 13, Fall: $55-79$.

- 1998. "The Escalating Irrelevance of Nuclear Weapons." In The Absolute Weapon Revisited: Nuclear Arms and the Emerging International Order, eds. T. V. Paul, Richard J. Harknett, and James J. Wirtz. Ann Arbor: The University of Michigan Press.

Paul, T, V. I998. "Power, Influence, and Nuclear Weapons: A Reassessment." In The $A b$ solute Weapon Revisited: Nudear Arms and the Emerging International Order, eds. T. V. Paul, Richard J. Harknett, and James J. Wirtz. Ann Arbor: The University of Michigan Press. Perry, William. 2006. "Proliferation on the Peninsula: Five North Korean Nuclear Crises." Annals of the American Academy of Political Science, 607, I: 78-86.

Raas, Whitney, and Austin Long. 2007. "Osirak Redux? Assessing Israeli Capabilities to Destroy Iranian Nuclear Facilities." Intemational Security 31 (4): 7-33.

Roberts, Brad. 2007. "All the Kings Men? Refashioning Global Order." International Affairs 83 (3): $523-30$.

Sagan, Scott D. 1994. "The Perils of Proliferation: Organization Theory, Deterrence Theory, and the Spread of Nuclear Weapons." International Security i8 (4): 66-107.

- 1995. "More Will Be Worse." In The Spread of Nuclear Weapons: A Debate, ed Scott D. Sagan and Kenneth Waltz. New York: W. W. Norton.

Sanger, David E., and William J. Broad. 2007. "U.S. Secretly Aids Pakistan in Guarding Nuclear Arms." New York Times. November 18. Available at http://www.nytimes $\mathrm{com} / 2007 / \mathrm{I} 1 / 18 /$ washington $/ \mathrm{I} 8$ nuke.html? $8 \mathrm{br}=$ \&pagewanted=all.

Sokolski, Henry. 2007. "Towards an NPT-Restrained World That Makes Economic Sense." Intemational Affairs 83 (3): $53 \mathrm{I}^{-4} 48$

Tellis, Ashley. 1997. Stability in South Asia. R.AND: Documented Briefing.

Walker, William. 2007. "Nuclear Enlightenment and Counter-Enlightenment." International Affairs 83 (3): $43 \mathrm{I}-\$ 4$.

Walt, Stephen M. 1987. The Origins of Alliances. Ithaca, N.Y.: Cornell University Press.

Waltz, Kenneth. I995. "More May Be Better." In The Spread of Nuclear Weapons: A Debate, ed. Scott D. Sagan and Kenneth Waltz. New York: W. W. Norton.

- 2004. "Nuclear Myths and political Realities." In The Use of Fore: Military Power and International Politics, ed. Robert J. Art and Kenneth N. Waltz. Boulder, Colo.: Rowman and Littlefield.

Wu, Xinbo. 1998. "China: Security Practice of a Modernizing and Ascending Power." In Asian Security Practice: Material and Ideational Influences, ed. Muthiah Alagappa. Stanford, Calif: Stanford University Press 